\title{
EFFICIENCY OF INSECTICIDE ,BIOCIDE AND RELEASE OF Trichograma evanescens WEST WOOD IN REDUCING COTTON BOLLWORMS INFESTATION AT KAFR EL- SHEIKH.
}

El-Agamy, F. M.*; F. A. Abou-Attia* ; M. M. Metwally ${ }^{\star *}$ and M. M. Ismail**

* Econ. Entomol. Dept., Fac. Agric., Kafrelsheikh Univ.

** Plant Prot. Dept., Sakha Agric. Res. St., Agric. Res. Cent.

\section{ABSTRACT}

This study was carried out at the Farm of Sakha Agricultural Research Station, Kafr El-Sheikh governorate during three successive seasons; 2008, 2009 and 2010 for assessing some agents for controlling the cotton bollworms, Pectinophora gossypiella (Saund.) and Earias insulana (Boisd.) Result showed that the most efficient insecticide against $P$. gossypiella larvae was sumi-alpha withe reduction 80.9 , 78.7 and $79.9 \%$ in the first spray while in the second spray the reduction were 82.1 , 85.2 and $83.7 \%$ in the three seasons of study, 2008, 2009, 2010 respectively Biovar and protecto were the least effective compounds in controlling this pest. As for Earias insulana larval population took almost the same trend with sumi-alpha while biovar and protecto were the least effective. Releasing trichograma evanescence West wood in two waves gave reduction for $P$. gossypiella and Earias insulana larvae with ranges of 31.7- 44.8 and $23.3-36.7 \%$ respectively .

\section{INTRODUCTION}

Cotton is considered one of the principle economic crops in Egypt. The pink bollworm, Pectinophora gossypiella (Saund.) and the spiny bollworm, Earis insulana (Boisd) are major pests attacking cotton in Egypt. Such pests may cause severe losses in cotton yield quantity and quality. (Abdel-Hafez et al, 2004)

Successful cotton production depends on efficient pest management program which reduces the risk of crop losses caused by cotton bollworms (El-Nagar, 2007).

Control of cotton bollworms by chemical insecticides is the main tool for combating such pests but repeated applications of insecticides on cotton and other crops induced many problems, including toxic and persistent environmental residues, development of pesticide resistant strains of pests and destruction of non-target organisms particularly beneficial natural enemies.( shawer, 2000 )

Bacillus thuringiensis var. kurstaki must be ingested by susceptible insect in order to be effective. This microorganism produces both spores (resting stage) and crystalline protein (an endotoxin) which becomes activated and binds to certain receptors in the insect gut causing pores through which gut contents can enter to the body cavity and bloodstream of the insect. The insect ceases feeding and dies within a few days (Tabashink et al., 2003) . 
Beauveria bassiana, (Balsamo) vuillemin is a pathogenic fungus with a large host range and is isused for insect biological control. $B$. bassiana infects and kills the pest when it comes in contact with the fungal spores. Once the fungal spores attach to the cuticle of insect, they germinate sending out structures (hyphae) that penetrate and proliferate in the body of the insect. (Long et al.,2000) .

Trichogramma evanescens (Westwood) was recorded in Egypt and reported to be an egg parasitoid for Sesamia cretica Led. and Chilo agamemnon Bles. (Kamal, 1951) and P. gossypiella (Abdel-Hafez et al, 2004). The release of $T$. evanescens is less costly than chemical sprays. At the same time, natural enemies are protected and environmental pollution is avoided during the outbreak years of bollworms. Both release of the parasite and spraying chemicals may be necessary.

The present study aimed to evaluate the efficiency of insecticide, biocide and release of Trichogramma evanescens in reducing cotton bollworm infestation.

\section{MATERIALS AND METHODS}

A field study was carried out at Sakha Agriculture Research Station Farm, Kafr El-Sheikh region during three successive seasons; 2008, 2009 and 2010.

An area of about one and half feddan, cultivated with Giza 86 cotton variety on March $20^{\text {th }}$ was assigned during three seasons. The normal agricultural practices were adopted throughout the growing season as recommended, but without any pesticides.

Effect of insecticide and biocide applications on cotton bollworm :

Insecticides and biocides belonging to different groups, were tested against cotton bollworm.

Trade name: Sumi-alpha

Common name: Esfenvalerate

Chemistry composition: (S)- $\alpha$-Cyano-3-phenoxybenzyl (S)-2-(4chlorophenyl)-3-methylbutyrate (IU PAC)<smiles>CC(C)[C@H](C(=O)O[C@H](C#N)c1cccc(Oc2ccccc2)c1)c1ccc(Cl)cc1</smiles> 


\section{Chemical structure:}

Protecto (10\% W.P):

A commercial formulation of Bacillus thuringiensis var. kurstaki and is a product of the special unit for producing Bioinsecticides, Plant Protection Research Institute, Agriculture Research Center, Egypt, with 3200 International toxicity Unit (IU). The active ingredient concentration is $9.4 \%$ and the application is was $500 \mathrm{~g} / \mathrm{feddan}$. It is a wetable powder formulation.

\section{Biovar:}

A trade name of the entomopathogenic fungus, Beauveria bassiana (Balasamo) as a liquid containing $3 \times 10^{7}$ conidia/ml. The recommended application rate is $200 \mathrm{~g} / 100$ water litter/feddan. The product was provided by El-Nasr Company for Fertilizers and Pesticides, Egypt.

The tested chemical and biocide compounds were applied twice; July $26^{\text {th }}$ and August $11^{\text {th }}$ during 2008, 2009 and 2010 cotton seasons. Knapsack sprayer ( $20 \mathrm{~L}$ volume) was used to spray the tested compounds. Numbers of insects were counted before spray, and then 1, 2, 3, 7 and 14 days after spray. Numbers of cotton bollworms were counted per 100 bolls. The reductions in bollworms populations were calculated using Abbott

(1925) equation as follows $=$ Population reduction \% = Where:

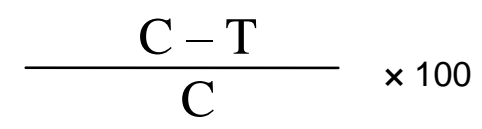

C: Number of bollworms in control.

$\mathrm{T}$ : Number of bollworms in treatment.

\section{Efficiency of the parasitoid, Trichogramma evanescens in reducing cotton bollworms infestations:}

During 2008, 2009 and 2010 cotton seasons, under natural infestation conditions, the egg-parasitoid, $T$. evanescens was released in small scale (half feddan) in two wave technique. The paper cards, containing the parasitoid eggs, were prepared at the Department of Biological Control of Plant Protection Research Institute, Giza, Egypt. The carton cards were inserted in vials with top and bottom covered with wire screen to allow the parasitoid adults to pass out and to prevent any predators to enter. The vials were attached to cotton plants by using pieces of wire. Each vial contained 1500 parasitized eggs, and cards were attached at $0.5 \mathrm{~m}$ high from the ground surface. To achieve the recommendation, spacings among parasitoid cards were approximately $15 \mathrm{~m}$.

For assessing the effectiveness of the parasitoid, T. evanescens in reducing bollworm numbers (pink and spiny bollworms), samples were taken 4,7 and 14 days after release. Each sample consisted of 100 bolls that were collected randomly from about 50 cotton plants. The boll samples were taken into plastic bags to the laboratory and dissected for estimating the boll infestation and the actual numbers of bollworm larvae per sample Percentage of reduction in numbers of bollworm larvae and infested bolls in the treated area were recorded. 
Statistical analysis:

To illustrate the data in Figures, the numbers were transformed using square root method to avoid the extreme values, Analysis of variance was computed in case of insecticide and biocide treatments, and means were compared using Duncan multiple range test (Duncan 1955)

\section{RESULTS AND DISCUSSION}

\section{Effect of insecticide and biocide application on cotton bollworm:}

Data in Table (1)and (2) show the efficiency of tested insecticides and biocides against bollworms under field conditions during three successive cotton seasons; 2008, 2009 and 2010.

Pink bollworm, Pectinophora gossypiella:

Data in Table(1) show that two sprays of Sumi-alpha in each of the three seasons proved to be the most effective against $P$. gossypiella, as the bollworm populations were reduced in the first spray by $80.9,78.7$ and 79.9 $\%$ for 2008, 2009 and 2010 seasons, respectively. In the second spray, the reductions were $82.1,85.2$ and $83.7 \%$ in the three seasons with overall averages of $81.6,81.9$ and 81.8 , respectively . Biovar and Protecto were not efficient in controlling this pest, In case of Biovar, the reductions in bollworm populations were $13.7 \& 13.9,15.7 \& 17.6$ and $15.7 \& 20.3 \%$ in the first and second sprays, respectively with overall averages $13.8,16.7$ and $18.0 \%$. Protecto casued reductions of $18.13 \& 14.86,18.7 \& 18.7$ and $22.2 \& 24.7$ in the first and second spray for three seasons, with overall average 16.5,18.7 and $23.4 \%$ respectively. The differences among treated compounds were significant.

These results are in line with those of Watson et al, (1981) and ElGhobary (2011) who recommended using alternations of pyrethroids and conventional insecticides for more effective control of $P$. gossypiella.

\section{Spiny bollworm, Earis insulana:}

Data in Table (2) show that, Sumi-alpha (pyrethroids) caused the highest reduction of spiny bollworm; $81.4 \& 83.7,81.3 \& 84.3$ and $78.3 \& 76.2 \%$ in the first and second sprays in both seasons, respectively with overall averages of $82.5,82.8$ and $77.2 \%$, respectively. However, Biovar was the least effective recording $15.1 \& 13.9,15.7 \& 13.2$ and $15.5 \& 12.2 \%$, respectively, in two sprays with overall averages of $14.5,14.4$ and13.9 \% The efficiencies of tested compounds differed significantly.

The obtained results agree with El-Ghobary (2011) ， Sharaf (2003) and El-Basyouni (2003) who reported that synthetic pyrethroids are considered the most efficient compounds and were superior to the other types of insecticides.

\section{Effeciency of Trichogramma evanescens in reducing cotton bollworms} infestation.

Table (3) shows that, during 2008, average percentages of reduction in the $1^{\text {st }}$ release of $T$. evanescens were $44.8,36.7$ in larvae of $P$. gossypiella and E. insulana, respectively. However, in the $2^{\text {nd }}$ release the percentages of reduction were 40.9 and $23.3 \%$ for both insects, respectively. 
J. Plant Prot. and Path., Mansoura Univ., Vol. 2 (8), August, 2011 
El-Agamy, F. M. et al.

2-3 
In 2009 season ,the redution was $38.2 \%$ for $P$. gossypiella and $30 \%$ reduction for $E$. insulana. However, in the second release, reduction was 33.9 and 27.7 to the first insect and second insect, respectively.

In 2010 season, the first release gave 35.1 and $33.3 \%$ reduction or $P$. gossyiella and Earias insulana espectively.However, in the second release the reduction was 31.7 and $26.5 \%$ to the first and second insects, respectively. These results are in agreement with El-Heneidy et al. (2004) and Abd El-Rahman et al. (2008) who reported that releasing Trichogramma parasitoid successfully reduced the losses in cotton yield.

\section{REFERENCES}

Abbott, W. S. (1925). A method of computing the effectiveness of an insecticide. J. Econ. Entomol., (18): 265-267.

Abd El-Hafez, A.M.; S.A.Aref and A.M.A.Azab(2004). Seasonal abundance and reduction percentages of the pink boll worm, pectinophora gossypiella(saund.) in Trichogramma releasing zones. J. Agric.Sci. Mansoura Univ., 29(9): 5291-5298.

Abd EL-Rahman, A. G.; A. M. Abd El-Hafaez; B. M. Sawaf; B. M. Refaie and A. I. Imam (2008). Efficacy of the egg parasitoid, Trichogramma evanescens West. in suppressing spiny bollworm, Earias insulana (Biosd) infestation in El-Farafra cotton fields, New Valley Governorate, Egypt. Egypt . J . Biol . P Cont ., 18 (2): 265-269.

Duncan,D.B.(1955)Multiple range and multiple F.tests, Biometries 11:1- 42.

El-Basyouni, S. A. (2003). Efficiency of some conventional insecticides on controlling the larvae of the bollworms. J. Agric. Sci. Mansoura Univ., 28 (3): 2363-2368.

El-Ghobary, A.M.A. (2011). Studies on some insect pests infesting cotton plants and their natural enemies at Kafr El-Sheikh Governorate. Ph.D. Thesis, Fac. Agric. Kafr El-Sheikh Univ., 128 pp.

El-Heneidy, A. H.; A. A. Khidr; A. M. Matar; A. Abd-elhalim and M. S. Hegab (2004). Proper timing and number of releases of the egg parasitoid, Trichogramma evanescens West. for controlling the cotton boll worms in Egyptian cotton fields. Egypt . J. Biol. P. Cont, 14 (1): 15-19.

El-Nagar, E. Y. A. (2007). The new approaches in control pink and spiny bollworms on cotton plants. M.Sc. Thesis, Fac. Agric. Kafr El-Sheikh Univ., $82 \mathrm{pp}$.

Kamal, M. (1951). The biological control of the cotton leaf worm, Prodenia litura F.in Egypt. Bull.Soc. ent. Egypt,35:221-268.

Long,D.W.;G.A.Drummond and E.Groden (2000). Horizntal transmission of Beauveria bassiana. Agriculture and forest Entomology,2:11-17.

Sharaf, F. H. (2003). Assessment the efficiency of certain different insecticides on both spiny and pink boll worms on cotton crop. J. Agric. Sci., Mansoura Univ., 28(3): 2369-2374.

Shawer, D.M.B.M. ( 2000 ) . Ecological studies on some iscect pests attacking cotton plants. M. Sc. Thesis, Fac . Agric., Kafr El- sheikh ,Tanta Univ ., $92 \mathrm{pp}$ 


\section{El-Agamy, F. M. et al.}

Tabashnik, B.E.; Y.Carriere; T.J. Dennehy; S. Morin; M.S.Sisterson; R.T.Roush; A.M.shelton and J. Z. Zhao (2003). Insect resistance to transgenic Bt crops. Lesson From laboratory and Field. J. Econ. Entomol.96:1031-1038.

Watson,W. M.; M. Abbasy and A.A.Zein (1981). Control effects of some new pyrethroids against the cotton boll worm, Pectinophora gossypiella (Saund.) and Earis insulana (Boisd.). Alex. J. Agric. Res.,29(3): 15111517.

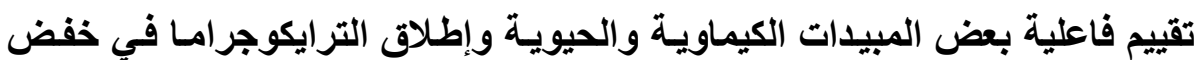

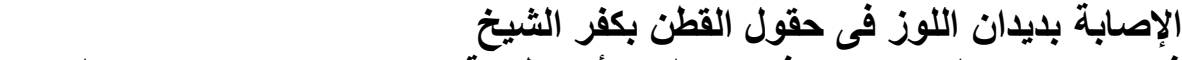

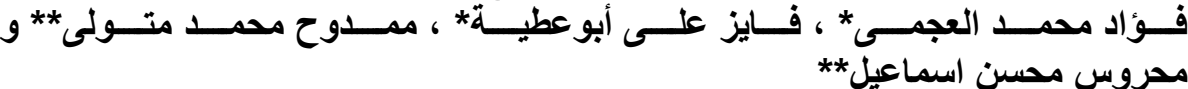

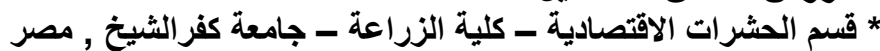

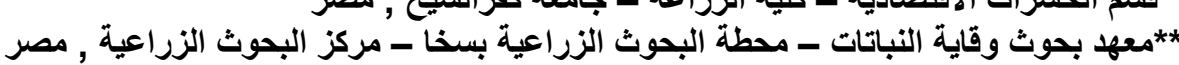

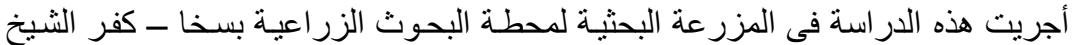

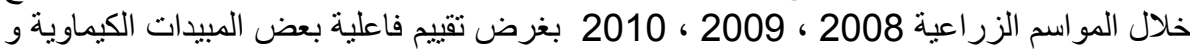
الحيوية وكذلك تأتثير إطلاق طفيل الترايكوجر امسا في خفض تعداد حشرتي دودة اللوز القرنفلية و أوضحت الدراسة أن مبيد Sumi- alpha هو الأكثر تأثير العلى دودني اللوز القرنفيلية

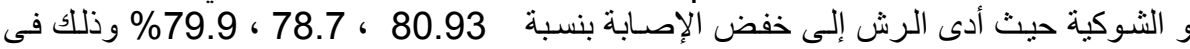

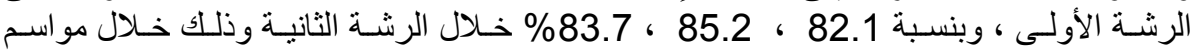

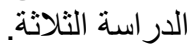

وكذلك أوضحت النتائج أن مبيد Sumi-alpha كان له نفس درجة التأثنير على دودة

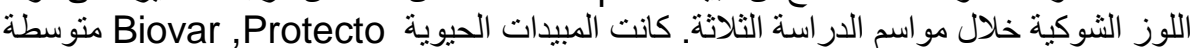

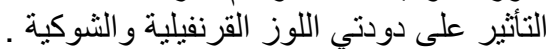

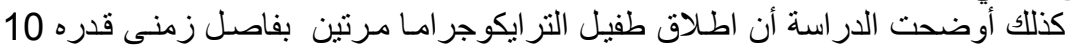

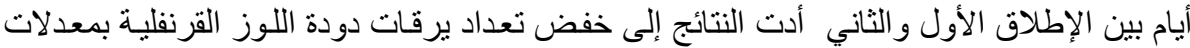

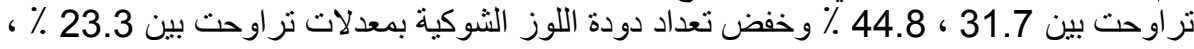
36.7 \% خلال سنو ات الدر اسة الثلاثة .

كلية الزراعة - جامعة المنصورة

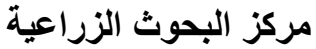

قام بتحكيم البحث

أ.د / سمير صالح عوض الله

أ.د / محمود رمزى شريف عوضف اله 
J. Plant Prot. and Path., Mansoura Univ., Vol. 2 (8), August, 2011 
Table (1): Reduction in Pectinophora gossypiella larvae (per 100 cotton bolls) as influenced by insecticide and biocide applications during 2008,2009 and 2010 cotton seasons at Kafr El-Sheikh region.

\begin{tabular}{|c|c|c|c|c|c|c|c|c|c|c|c|c|c|c|c|c|c|c|c|c|c|c|}
\hline \multirow[b]{2}{*}{ 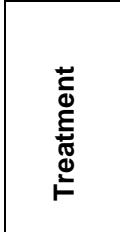 } & \multirow[b]{2}{*}{ 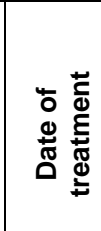 } & \multicolumn{7}{|c|}{2008} & \multicolumn{7}{|c|}{$\begin{array}{c}2009 \\
\text { Population reduction \% }\end{array}$} & \multicolumn{7}{|c|}{2010} \\
\hline & & $\frac{\vec{\pi}}{0}$ & $\begin{array}{l}\stackrel{n}{2} \\
\underset{0}{0} \\
\text { N }\end{array}$ & $\begin{array}{l}\stackrel{n}{7} \\
\frac{\pi}{0} \\
m\end{array}$ & $\overbrace{\substack{\frac{1}{0} \\
\Lambda}}^{0}$ & 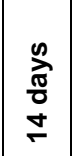 & $\begin{array}{l}\frac{0}{\pi} \\
\frac{\pi}{\omega} \\
\frac{\pi}{\alpha}\end{array}$ & 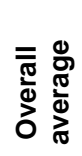 & 离 & $\begin{array}{l}\stackrel{0}{2} \\
\text { तั } \\
\text { N }\end{array}$ & 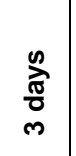 & 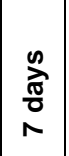 & 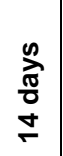 & 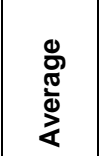 & 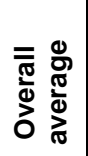 & $\frac{\vec{\pi}}{0}$ & $\begin{array}{l}\stackrel{n}{\pi} \\
\stackrel{\pi}{0} \\
\text { N }\end{array}$ & $\begin{array}{l}\stackrel{n}{2} \\
\frac{\pi}{0} \\
0\end{array}$ & $\begin{array}{l}\frac{\infty}{2} \\
\frac{\pi}{0} \\
\end{array}$ & 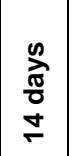 & 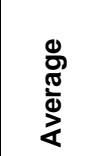 & 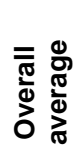 \\
\hline Control & & 0.0 & 0.0 & 0.0 & 0.0 & 0.0 & $0.0 \mathrm{a}$ & R & 0.0 & 0.0 & 0.0 & 0.0 & 0.0 & $0.0 \mathrm{a}$ & O & 0.0 & 0.0 & 0.0 & 0.0 & 0.0 & $0.0 \mathrm{a}$ & 0 \\
\hline & & 0.0 & 0.0 & 0.0 & 0.0 & 0.0 & $0.0 \mathrm{a}$ & 0.0 & 0.0 & 0.0 & 0.0 & 0.0 & 0.0 & $0.0 \mathrm{a}$ & 0.0 & 0.0 & 0.0 & 0.0 & 0.0 & 0.0 & $0.0 \mathrm{a}$ & 0.0 \\
\hline Sumi- & $\frac{26 \mathrm{July}}{11 \mathrm{~A} u}$ & \begin{tabular}{|l|}
66.7 \\
73.3 \\
\end{tabular} & \begin{tabular}{|l|}
80.0 \\
80.0
\end{tabular} & \begin{tabular}{|l|}
85.7 \\
87.5 \\
\end{tabular} & \begin{tabular}{|l|}
90.0 \\
917
\end{tabular} & \begin{tabular}{|l|}
84.7 \\
857 \\
\end{tabular} & $81.4 \mathrm{c}$ & 82.5 & \begin{tabular}{|l|l|}
72.8 \\
750
\end{tabular} & \begin{tabular}{|l|}
80.0 \\
9177
\end{tabular} & \begin{tabular}{|l|}
75.0 \\
875.
\end{tabular} & 88.9 & 90.0 & \begin{tabular}{|l}
$81.3 d$ \\
\end{tabular} & 82.8 & 66.7 & 80.0 & 83.3 & 88.9 & 72.8 & $78.3 c$ & 77.2 \\
\hline & 26July & $\begin{array}{l}71.0 \\
11.1\end{array}$ & 0.0 & \begin{tabular}{|l|}
18.1 \\
\end{tabular} & 25.0 & \begin{tabular}{|l|}
21.4 \\
\end{tabular} & $15.1 \mathrm{~b}$ & & 0.0 & \begin{tabular}{|l|l|}
0.0 \\
\end{tabular} & $\frac{\mid}{25.0}$ & \begin{tabular}{|l|} 
\\
23.0 \\
\end{tabular} & 21.0 & $\frac{04.0 \mathrm{~d}}{15.7 \mathrm{~b}}$ & & 10.0 & $\frac{72.8}{14.2}$ & \begin{tabular}{|c|}
15.0 \\
8.3 \\
\end{tabular} & \begin{tabular}{|l|}
90.0 \\
30.8 \\
\end{tabular} & \begin{tabular}{|l|}
14.3 \\
14.2 \\
\end{tabular} & $\frac{76.2 c}{15.5 b}$ & \\
\hline Biovar & 11 Aug & 0.0 & 8.3 & 18.1 & 23.0 & 20.0 & $13.9 \mathrm{~b}$ & 14.5 & 9.0 & 0.0 & 28.6 & 15.3 & 13.3 & $13.2 \mathrm{~b}$ & 14.4 & 7.7 & 13.3 & 0.0 & 26.7 & 13.3 & $12.2 \mathrm{~b}$ & 13.9 \\
\hline Protectc & $\frac{26 \text { July }}{11 \text { Aug }}$ & \begin{tabular}{|l|}
12.5 \\
0.0
\end{tabular} & 10.0 & \begin{tabular}{|l|}
20.0 \\
20.0
\end{tabular} & \begin{tabular}{|l|}
25.0 \\
35.8
\end{tabular} & \begin{tabular}{|l|}
35.8 \\
33.3 \\
\end{tabular} & $\frac{20.7 b}{19.3 b}$ & 20.0 & $\frac{20.0}{16.7}$ & \begin{tabular}{|c|}
16.7 \\
14.2
\end{tabular} & $\begin{array}{l}30.0 \\
9.0 \\
\end{array}$ & \begin{tabular}{|l|}
30.8 \\
37.5
\end{tabular} & $\frac{28.6}{20.0}$ & \begin{tabular}{|c|}
$25.2 c$ \\
$19.4 b c$
\end{tabular} & 22.3 & $\frac{20.0}{28.6}$ & \begin{tabular}{|l|}
16.7 \\
15.3
\end{tabular} & \begin{tabular}{|l|}
10.0 \\
6.7
\end{tabular} & \begin{tabular}{|l|}
11.1 \\
18.1
\end{tabular} & \begin{tabular}{|l|}
23.0 \\
13.3 \\
\end{tabular} & \begin{tabular}{|l|}
$16.1 \mathrm{~b}$ \\
$16.4 \mathrm{~b}$
\end{tabular} & 16.2 \\
\hline
\end{tabular}

Means followed by a common letter are not significantly different at the $5 \%$ level by DMRT 
Table (2): Reduction in Earis insulana Iravae (per 100 cotton bolls) as influenced by insecticide and biocide during 2008,2009 and 2010 cotton season at Kafr El-Sheikh region.

\begin{tabular}{|c|c|c|c|c|c|c|c|c|c|c|c|c|c|c|c|c|c|c|c|c|c|c|}
\hline \multirow[b]{2}{*}{ 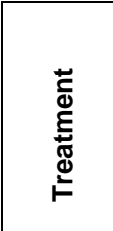 } & \multirow[b]{2}{*}{ 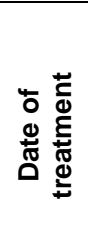 } & \multicolumn{7}{|c|}{$\begin{array}{c}2008 \\
\text { Population reduction \% }\end{array}$} & \multicolumn{7}{|c|}{$\begin{array}{c}2009 \\
\text { Population reduction \% }\end{array}$} & \multicolumn{7}{|c|}{$\begin{array}{c}2010 \\
\text { Population reduction \% }\end{array}$} \\
\hline & & 중 & $\begin{array}{l}\stackrel{n}{\pi} \\
\underset{\delta}{0} \\
\text { N }\end{array}$ & 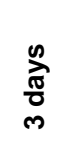 & $\frac{\substack{0 \\
\frac{\pi}{0}}}{r}$ & 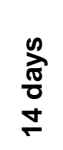 & 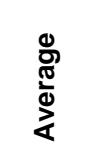 & 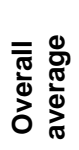 & $\frac{\text { बे }}{0}$ & 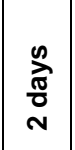 & 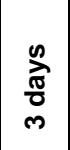 & $\frac{n}{\stackrel{\pi}{0}}$ & 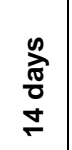 & 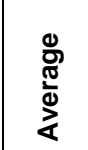 & 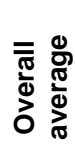 & $\frac{\text { ते }}{8}$ & 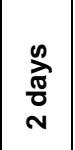 & $\begin{array}{l}\stackrel{n}{7} \\
\frac{\pi}{0} \\
\infty\end{array}$ & 弯 & 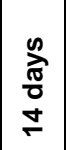 & 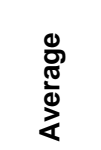 & 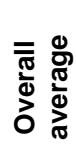 \\
\hline \multirow{2}{*}{ Control } & & 0.0 & 0.0 & 0.0 & 0.0 & 0.0 & $0.0 \mathrm{a}$ & \multirow[b]{2}{*}{0.0} & 0.0 & 0.0 & 0.0 & 0.0 & 0.0 & $0.0 \mathrm{a}$ & \multirow[b]{2}{*}{0.0} & 0.0 & 0.0 & 0.0 & 0.0 & 0.0 & $0.0 \mathrm{a}$ & \multirow[b]{2}{*}{0.0} \\
\hline & & 0.0 & 0.0 & \begin{tabular}{|l|}
0.0 \\
\end{tabular} & 0.0 & 0.0 & $0.0 \mathrm{a}$ & & 0.0 & 0.0 & \begin{tabular}{|l|}
0.0 \\
\end{tabular} & 0.0 & 0.0 & $0.0 \mathrm{a}$ & & 0.0 & 0.0 & 0.0 & 0.0 & \begin{tabular}{|l|}
0.0 \\
\end{tabular} & $0.0 \mathrm{a}$ & \\
\hline \multirow{2}{*}{$\begin{array}{l}\text { Sumi- } \\
\text { alpha }\end{array}$} & 26July & 62.5 & 80.0 & 83.4 & 88.9 & 90.0 & $80.9 \mathrm{c}$ & \multirow[t]{2}{*}{81.6} & 55.6 & 70.0 & 83.3 & 91.7 & 92.9 & $78.7 \mathrm{c}$ & \multirow[t]{2}{*}{81.9} & 63.7 & 77.8 & 85.8 & 92.3 & 80.0 & $79.9 d$ & \multirow[t]{2}{*}{81.8} \\
\hline & 11Aug & 69.2 & 81.9 & 80.0 & 92.8 & 86.7 & $82.1 \mathrm{c}$ & & 80.0 & \begin{tabular}{|l|}
77.8 \\
\end{tabular} & 88.9 & 92.9 & \begin{tabular}{|l|}
86.7 \\
\end{tabular} & $85.2 \mathrm{c}$ & & 80.0 & 83.3 & 77.8 & 87.5 & 90.0 & $83.7 d$ & \\
\hline \multirow{2}{*}{ Biovar } & 26July & 0.0 & 7.7 & \begin{tabular}{|l|}
8.4 \\
\end{tabular} & 21.5 & 31.3 & $13.7 \mathrm{~b}$ & \multirow[t]{2}{*}{13.8} & 9.0 & 15.8 & 25.0 & 0.0 & 23.6 & $15.7 b$ & \multirow[t]{2}{*}{16.7} & 9.0 & 8.3 & 20.0 & 18.1 & 23.0 & $15.7 \mathrm{~b}$ & \multirow[t]{2}{*}{18.0} \\
\hline & 11Aug & 7.1 & 0.0 & 21.5 & 28.6 & 12.5 & $13.9 b$ & & 0.0 & 20.0 & \begin{tabular}{|l|}
18.1 \\
\end{tabular} & 23.0 & 26.7 & $17.6 \mathrm{~b}$ & & 7.1 & 20.0 & 25.0 & 23.0 & 26.7 & $20.3 b c$ & \\
\hline \multirow{2}{*}{ Protecto } & 26July & 11.1 & 18.1 & 25.0 & 23.0 & 13.4 & $18.1 \mathrm{~b}$ & \multirow{2}{*}{16.5} & 10.0 & 27.2 & 23.0 & 10.0 & 10.0 & $18.7 \mathrm{~b}$ & \multirow{2}{*}{18.7} & 8.3 & 16.7 & 36.3 & 23.0 & 26.7 & $22.2 \mathrm{bc}$ & \multirow[b]{2}{*}{23.4} \\
\hline & 11Aug & 14.3 & 16.7 & 6.6 & 18.8 & 17.7 & $14.8 \mathrm{~b}$ & & 8.3 & 13.3 & 20.0 & 25.0 & 25.0 & $18.7 \mathrm{~b}$ & & 7.7 & 26.7 & 30.8 & 33.3 & 25.0 & $24.7 \mathrm{~b}$ & \\
\hline
\end{tabular}

Means followed by a common letter are not significantly different at the $5 \%$ level by DMRT

Table (3): Efficacy of Trichogramma evanescens release on the reduction percentage of Pectionophora gossypiella and Earis insulana larvae during 2008,2009 and 2010 cotton season at Kafr El-Sheikh region.

\begin{tabular}{|c|c|c|c|c|c|c|}
\hline \multirow{3}{*}{ insect } & & \multicolumn{5}{|c|}{2008} \\
\hline & & \multicolumn{5}{|c|}{ Population reduction \% } \\
\hline & & 4 days & 7 days & 14 days & Total & Average \\
\hline \multirow{2}{*}{\begin{tabular}{|l|} 
P. gossypiella \\
E. insulana \\
\end{tabular}} & \multirow{2}{*}{$1^{\text {st }}$ release } & 50.0 & 66.7 & 17.7 & 134.4 & $44.8 \mathrm{a}$ \\
\hline & & 46.4 & 50.0 & 13.3 & 110.0 & $36.7 a$ \\
\hline P. gossypiella & \multirow{2}{*}{$-2^{\text {nd }}$ release } & 25.0 & 60.0 & 37.5 & 122.5 & $40.9 a$ \\
\hline E. insulana & & 33.3 & 20.0 & 16.7 & 70.0 & $23.3 a$ \\
\hline \multicolumn{7}{|l|}{2009} \\
\hline P. gossypiella & \multirow{2}{*}{$1^{\text {st }}$ release } & 33.3 & 54.6 & 26.7 & 114.6 & $38.2 \mathrm{~b}$ \\
\hline E. insulana & & 20.0 & 50.0 & 20.0 & 90.0 & $30.0 a b$ \\
\hline P. gossypiella & \multirow{2}{*}{$2^{\text {nd }}$ release } & 16.7 & 50.0 & 35.0 & 101.7 & $33.9 a$ \\
\hline E. insulana & & 26.7 & 37.0 & 18.8 & 83.0 & $27.7 a$ \\
\hline \multicolumn{7}{|l|}{2010} \\
\hline \multirow{2}{*}{\begin{tabular}{|l|} 
P. gossypiella \\
E. insulana \\
\end{tabular}} & \multirow{2}{*}{$1^{\text {st }}$ release } & 33.3 & 47.0 & 25.0 & 105.3 & $35.1 \mathrm{a}$ \\
\hline & & 28.6 & 40.0 & 31.5 & 100.1 & $33.3 a$ \\
\hline P. gossypiella & \multirow{2}{*}{$-2^{\text {nd }}$ release } & 35.0 & 35.0 & 25.0 & 95.0 & $31.7 a$ \\
\hline E. insulana & & 36.8 & 25.0 & 17.7 & 79.5 & $26.5 a$ \\
\hline
\end{tabular}




\section{El-Agamy, F. M. et al.}

